\title{
Flavonoid Compounds From The Leaves Of Kalanchoe Tomentosa And Their Cytotoxic Activity Against P-388 Murine Leukemia Cell
}

\author{
Lilis Siti Aisyah* ${ }^{1,2,}$, Yenny Febriani Yun ${ }^{1,2}$, Ade Akbar Abdilla ${ }^{1}$, \\ Tati Herlina ${ }^{1}$, Euis Julaeha ${ }^{1}$, Unang Supratman, ${ }^{*} *^{1}$
}

\author{
${ }^{I}$ Natural Product Chemistry Group, Department of Chemistry, The Faculty of Mathematics and Natural \\ Sciences, Padjadjaran University, Bandung-Sumedang Km 21, \\ Jatinangor, Sumedang 45363 \\ ${ }^{2}$ Department of Chemistry, The Faculty of Mathematics and Natural Sciences, Jenderal Achmad Yani \\ University, Cimahi 40528 \\ Corresponding author: *lies.syarifudin@gmail.com, **u_supratman@unpad.ac.id \\ ${ }^{3}$ The Faculty of Pharmacy, Jenderal Achmad Yani University, Cimahi 40528
}

\begin{abstract}
Kalanchoe plant, known as "sosor bebek" in Indonesia is a perennial herb and has succulent leaves. The plant is known in folklore and traditional medicine in Indonesia for the treatment of fever, abscesses, bruises, contused wounds, coughs and skin diseases. During the course of our continuing search for novel cytotoxic compounds, the methanolic extract of Kalanchoe tomentosa plants showed cytotoxic activity against P-388 murine leukemia cells. The methanolic extract of the fresh leaves of $K$. tomentosa was concentrated and extracted successively with $n$-hexane, ethyl acetate and $n$-butanol. The ethyl acetate extract exhibited strongest cytotoxic activity againts P-388 murine leukemia cells. By using the cytotoxic activity to follow the separation, the ethyl acetate fraction was separated by combination of column chromatography on silica gel and preparative TLC on silica gel $\mathrm{GF}_{254}$ to afford a kaempferol-3-O-glycosides (1) and kaempferol-3-O-rhamnoside (2). Compound $\mathbf{1}$ and $\mathbf{2}$ showed cytotoxic activity against P-388 murine leukemia cells with $\mathrm{IC}_{50}>100 \mu \mathrm{g} / \mathrm{mL}$ and $\mathrm{IC}_{50} 3.32 \mu \mathrm{g} /$ $\mathrm{mL}$.
\end{abstract}

Keywords: P-388 murine leukemia cells, kaempferol-3$O$-glycosides, Kaempferol-3-Orhamnoside, Kalanchoe tomentosa
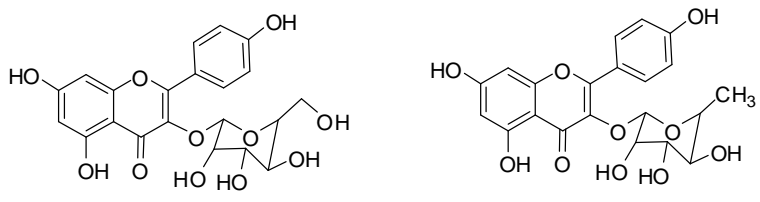

2

\section{INTRODUCTION}

Kalanchoe tomentosa belongs to the family Crassulaceae is a beatiful, perennial and succulent plant. Genus Kalanchoe consists of about 130 species of annual and perennial shrubs. The plant ussually occur in semi desert of Saudia Arabia, Yemen, CentarlAfrica, Madagascar, tropical areas of Asia, Australia, and tropical America. Ussually, it is cultivated as garden ornamental and sand gardens with a medium humidity ${ }^{1)}$.

Kalanchoe plants are used as traditional medicines to cure headache, cough, chest pain, ulcer, and other skin deseases. They overcome fever, fix the irregular menstruation, heal wound and boil, not only in Indonesia but also almost everywhere in the world ${ }^{2)}$. Some researches reported that Kalanchoe plants contain bufadienolide $^{3,4)}$, triterpenoid $^{5)}$, and flavonoid ${ }^{6,7)}$, and biological activities like antileismanial, antiinflamatory, cytotoksic, and inhibiting tumor cell growth4). One of unknown Kalanchoe plants ethnopharmacologically is Kalanchoe tomentosa, especially its anticancer activity. Cancer is a disease that is becoming one of the major threats to health as it is the second cause of death after heart disease. In Indonesia reported increased cancer deaths each year ranging $1.4 \%$ in 1972 to $4.4 \%$ in $1992^{8}$. In coping with cancer, various efforts had been whom did seek anticancer compounds from plants. 
In this research, the anticancer activity of $K$. tomentosa leave extract phenolic compound was tested, followed by isolation, structure determination.

\section{EXPERIMENTAL}

\subsection{Materials}

Plant

The leaves of $K$. tomentosa were collected from Lembang, West Bandung area, West Java, Indonesia, and identified at Herbarium Bogoriense, Biology Research Center of LIPI Lembaga Ilmu Pengetahuan Indonesia or LIPI (The Indonesian Institute of Sciences), Cibinong, Bogor, West Java, Indonesia.

\section{Chemical}

The chemicals needed were both the various technical solvents (redestiled), like $n$-heksane, methanol, aceton, and pro-analysis ones, like dichloromethane and chloroform. Silica $\mathrm{GF}_{254}$ was used in Thin Layer Chromatography (TLC), Silica-G60 $(10-40 \mu \mathrm{m})$ with the surface area $(500$ $\mathrm{m}^{2} / \mathrm{g}$ ) was used in vacuum liquid chromatography, and silica G60 (70-230 and 230-400 mesh) were used in the open column chromatography, and the solution of $\mathrm{AlCl}_{3}$ (10\% in ethanol) as stain-display reagent.

\section{Equipments}

The equipments used were glass wares common in organic chemistry laboratory, macerator, rotary evaporator R-200 Buchi with vacuum pump Vac V-500 Buchi and water heater B-490 Buchi, open chromatography column with various sizes, UV lamp Vilbert Luomart ( $\lambda 254$ $\mathrm{nm}$ dan $\lambda 365 \mathrm{~nm}$ ), spectrophotometer FTIR Spectrum One Perkin Elmer, Spectrometer Nuclear Magnetic Resonance (NMR) JEOL JNM ECA-500 with TMS as internal standard.

\subsection{Methods}

Bioassay using murine leukemia cells $P-388^{9)}$

P-388 cancer cells cultured in RPMI-1640 medium were given calf serum 5\% and kanamycin $(100 \mu \mathrm{g} / \mathrm{mL})$. Cells $(3 \times 3$ cells / well $)$ were seeded into 96 well plates composed of 100 $\mathrm{L}$ growth medium per well and incubated in a humidifier $37^{\circ} \mathrm{C}$ in $5 \% \mathrm{CO}_{2}$. Several variations of the compounds $(10 \mu \mathrm{L})$ was added into the culture at the PER all after transplantation. On the third day of $20 \mu \mathrm{L}$ solution of MTT $(5 \mathrm{mg} / \mathrm{mL})$ per well was added to each culture medium. After 4 hours of incubation, a solution of $100 \mathrm{~mL}$ of $10 \%$ SDS was added each $\mathrm{HCl} 0.01 \mathrm{~N}$ wells and formazan crystals in each well were dissolved by stirring with a pipette. After the solution was measured using an optical densiti mikroplat reader (MPR-A4i Tohso) or ELISA reader at a wavelength of 550 and $700 \mathrm{~nm}$. The experiments were conducted by measuring triplo

\section{Extraction and Isolation}

The $18,3 \mathrm{~kg}$ of fresh $\mathrm{K}$. tomentosa leave was grinded, extracted, and then concentrated. The $390.75 \mathrm{~g}$ of methanol extract obtained was dissolved in water and partitioned respectively using $\mathrm{n}$-hexane and ethyl acetate, yielding in $\mathrm{n}$ hexane extract ( $20 \mathrm{~g})$ and ethyl acetate extract (10 g). The ethyl acetate extract was fractioned using liquid vacuum chromatography with gradient system using a variety of solvents including nhexane,ethyl acetate and methanol, resulted in 8 combined fractions. The fraction combination was performed through the thin layer chromatography guiding under the UV lamp $254 \mathrm{~nm}$ with staindisplaying reagent $10 \% \mathrm{AlCl} 3$ in ethanol. Out of the 8 combined fractions, the fraction 5 was further fractioned, obtained 6 combination wherein at 5 and 6 formed yellow precipitate as compound 1 (15 mg) and compound 2 (10 mg).

Compounds 1 and 2 which show the pattern of the stain for multiple comparisons solvent was then characterized using spectroscopy

Senyawa (1) Kaempferol-3-O-glicoside (astragalin) : yellow powder (5 mg); $\mathrm{UV}(\mathrm{MeOH})$ $\lambda_{\max }(\mathrm{nm})(\log \varepsilon): 273,333 ; \mathrm{IR}(\mathrm{KBr}) \mathrm{V}_{\max }\left(\mathrm{cm}^{-1}\right)$ : 3243, 1711, 1660, 1182-1081. Spektrum ${ }^{1} \mathrm{H}$ NMR (400 MHz, aseton- $\left.\mathrm{d}_{6}\right)$ (ppm) : see table 1.Spektrum ${ }^{13} \mathrm{C}-\mathrm{NMR} \quad\left(100 \mathrm{MHz}\right.$, aseton- $\left.\mathrm{d}_{6}\right)$ (ppm): see table 1.Data HR-EIMS $\mathrm{m} / z \quad[\mathrm{M}]^{+}$ 432 calculation for $\mathrm{C}_{21} \mathrm{H}_{20} \mathrm{O}_{10}$.

Compound (2) Kaempferol-3-O-rhamnoside (afzelin) : yellow powder $(10 \mathrm{mg})$; UV $(\mathrm{MeOH})$ $\lambda_{\max }(\mathrm{nm})(\log \varepsilon): 341,264 \quad . \mathrm{IR}(\mathrm{KBr}) \mathrm{V}_{\max }\left(\mathrm{cm}^{-}\right.$ $\left.{ }^{1}\right)$ : 3278, 2900, 1655, 1470, 1062. ${ }^{1} \mathrm{H}$ NMR spectra $\left(400 \mathrm{MHz}\right.$, aceton- $\left.\mathrm{d}_{6}\right)(\mathrm{ppm})$ : see table 1 . ${ }^{13} \mathrm{C}-\mathrm{NMR}$ spectra $\left(100 \mathrm{MHz}\right.$, aseton- $\left.\mathrm{d}_{6}\right)(\mathrm{ppm})$ : see table 1. Data HR-EIMS m / z [M] + 431 (calculation of $[\mathrm{M}]+$ for $\mathrm{C}_{21} \mathrm{H}_{20} \mathrm{O}_{10}$ 


\section{RESULT AND DISCUSSION}

The ethyl acetate was fractionated using various methods of chromatography, a yellow precipitate was obtained which was identified as kaempferol by comparison of the NMR spectral data. Same aglycone obtained for both compounds 1 and 2 .
Compound 1 has hydroxy group of glycoside at $\delta \mathrm{H} 3.43(\mathrm{~d}, 1 \mathrm{H}) ; 3,48(\mathrm{~m}, 1 \mathrm{H}) ; 3.73(\mathrm{dd}, 1 \mathrm{H} ; 5.5$; $11.2 \mathrm{~Hz}$ ), whereas in compound 2 showed the prsence of an anomeric proton as a doublet at 5.32 suggesting a sugar residu in its structure which was identified as L-rhamnosyl moiety on the basis of acid hydrolysis

Table $1 \mathrm{H}$ and $13 \mathrm{C}$ NMR chemical shift values for compounds 1 and 2 in CD3OD

\begin{tabular}{|c|c|c|c|c|}
\hline \multirow{2}{*}{ Position } & \multicolumn{2}{|l|}{1} & \multicolumn{2}{|l|}{2} \\
\hline & $\delta_{\mathrm{H}}$ & $\delta_{\mathrm{C}}$ & $\delta_{\mathrm{H}}$ & $\delta_{\mathrm{C}}$ \\
\hline 2 & - & 156.3747 & - & 158,6 \\
\hline 3 & - & 133.2633 & - & 136,3 \\
\hline 4 & - & 177.5688 & - & 179,7 \\
\hline 5 & - & 161.3155 & - & 163,3 \\
\hline 6 & $6.30(\mathrm{~d}, 1 \mathrm{H}, \mathrm{J}=2.4 \mathrm{~Hz})$ & 98.8014 & $6,19(1 \mathrm{H} ; d ; 2)$ & 99,9 \\
\hline 7 & - & 164.2247 & - & 165,9 \\
\hline 8 & $6.54(\mathrm{~d}, 1 \mathrm{H}, \mathrm{J}=2.4 \mathrm{~Hz})$ & 93.7651 & $6,35(1 \mathrm{H}, d ; 2)$ & 94,9 \\
\hline 9 & - & 156.4796 & - & 159,4 \\
\hline 10 & - & 104.1142 & - & 105,9 \\
\hline $1 '$ & - & 121.0066 & - & 122,7 \\
\hline $2 ' / 6 ’$ & $6.893(\mathrm{~d}, 2 \mathrm{H}, \mathrm{J}=9.0 \mathrm{~Hz})$ & 131.0123 & $7,75(1 \mathrm{H}, d d, 8,9)$ & 132 \\
\hline $3 ' / 5$ & $8.064(\mathrm{~d}, 2 \mathrm{H}, \mathrm{J}=9.0 \mathrm{~Hz}$ & 115.2168 & $6,93(1 \mathrm{H}, d d, 9,0)$ & 116,6 \\
\hline $4^{\prime}$ & - & 160.0374 & - & 161,7 \\
\hline \multicolumn{5}{|l|}{ Sugar } \\
\hline \multirow[t]{2}{*}{$1 ”$} & $5.269(\mathrm{~d}, 1 \mathrm{H}, \mathrm{J}=7.8$ & & $5,32(1 \mathrm{H}, d, 2)$ & 103,6 \\
\hline & $\mathrm{Hz})$ & 100.9284 & & \\
\hline \multirow[t]{2}{*}{$2 "$} & $3.179-3.701(\mathrm{~m}, 5 \mathrm{H}$ & & $4,22(1 \mathrm{H}, d d, 2$ & 72,1 \\
\hline & glucoside) & 74.3070 & $3,25)$ & \\
\hline \multirow[t]{2}{*}{$3 "$} & - & & $3,71(1 \mathrm{H}, d d, 3,25$ & 72,2 \\
\hline & & 76.4912 & 9) & \\
\hline $4 "$ & - & 69.9670 & $3,33(1 \mathrm{H}$ & 73,3 \\
\hline $5 "$ & - & 77.5881 & 3,32 (1H,m) & 72 \\
\hline 6" & - & 60.9152 & $0,93(3 \mathrm{H}, d, 5,7)$ & 17,8 \\
\hline
\end{tabular}

Anticancer activity (murine leukemia cells P-388 to the risk) showed potent anticancer compounds with $\mathrm{IC}_{50}>100 \mu \mathrm{g} / \mathrm{mL}$ and $\mathrm{IC}_{50} 3.32 \mu \mathrm{g} / \mathrm{mL}$. This value indicates that the compound (2) is very active as anticancer flavonoids. According to Alley et $\mathrm{al}^{9 \text { ). }}$ strong anticancer activity is expressed as

$1 \mathrm{IC}_{50} 5 \mu \mathrm{g} / \mathrm{mL}=$ very active;

$2 \mathrm{IC}_{50}$ of $5-10 \mu \mathrm{g} / \mathrm{mL}=$ active;

$3 \mathrm{IC}_{50} 11-30 \mu \mathrm{g} / \mathrm{mL}=$ moderate; and

$4 \mathrm{IC}_{50}>30 \mu \mathrm{g} / \mathrm{mL}=$ not active

The discovery of these compounds on the type of Kalanchoe tomentosa was reported for the first time in this research

\section{CONCLUSION}

From the results of the isolation of ethyl acetate fraction kalanchoe tomentosa plants produce compounds of the flavonoid group Kaempferol 3-Oa-glycoside (1) and Kaempferol 3-Oa-ramnosida (2). Compound $\mathbf{1}$ and $\mathbf{2}$ showed cytotoxic activity against P-388 murine leukemia cells with $\mathrm{IC}_{50}>100 \mu \mathrm{g} / \mathrm{mL}$ and $\mathrm{IC}_{50} 3.32 \mu \mathrm{g} / \mathrm{mL}$ 


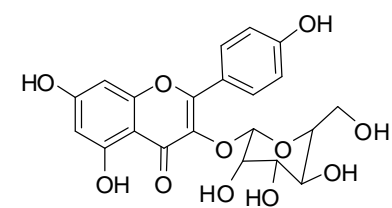

!

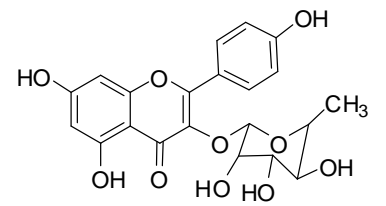

2
Fig. 1. The chemical structure of Kaempferol 3Oa-glycoside (1) and Kaempferol 3-Oa-ramnosida (2)

\section{ACKNOWLEDGMENTS}

We thank Herbarium Bogoriense, Biology Research Center of Lembaga Ilmu Pengetahuan Indonesia or LIPI (The Indonesian Institute of Sciences), Cibinong, Bogor, West Java, Indonesia, and Chemistry Research Center of LIPI Serpong, Tangerang for their support in measuring the spectra NMR. The staff of Medical Pharmacokinetic Laboratory of Padjadjaran University, thank you for measuring the MS.

\section{REFERENCES}

1. Souza-Brito, A.R.M. and A.A. SouzaBrito. 1993. Forty years of Brazilian medicinal plant reasearch. Journal of Ethnopharmacology, 39(1); 53-67

2. Quazi, M.A., Tatiya, A., Khurshid, M., Nazim, S and Siraj, S., 2011, The Miracle Plant (Kalanchoe pinnata) a Phytochemical and Pharmacological Review, IJRAP, 2(5): 14781482

3. Supratman, U., Fujita, T., Akiyama, K., Hayashi, H., 2000, New insecticidal bufadienolide, bryophyllin $\mathrm{C}$, from Kalanchoe pinnata. Biosci. Biotechnol. Biochem. 64, 1309-1311.

4. Supratman, U., Fujita, T., Akiyama, K., and Hayashi, H., 2001, Insecticidal compounds from Kalanchoe daigremontiana x tubiflora, Phytochemistry., 58, 311-314.

5. Gaind, C.A and Gupta, R.L., 1972, Alkanes, alkanols, triterpenes, and sterols of Kalanchoe pinnata, Phytochemistry, 11, 1500-1502.

6. Muzitano, M.F., Tinoco, L.W., Guette, C., Kaiser, C.R., Bergmann, B.R., and Costa, S.S,
2006, The antileishmanial activity assesment of unusual flavonoids from Kalanchoe pinnata, Phytochemistry, 67, 2071-2077.

7. Okwu, D.E., and Nnamdi, F.U., 2011, Two novel flavonoids from Bryophyllum pinnatum and heir antimicrobial Activity. J. Chem. Pharm. Res., 3(2),1-10.

8. Atta-ur-Rahman, M.I. Choudhary, dan W.J. Thomsen, 2001, Bioassay Techniques For Drug Development, Harwood Academic Publisher, San Diego, USA.

9. Alley, M.C., Scudiare, D.A., Monks, M., Hursey, M.L., Czerwinski, M.J., dan Fine, D.L., (1988): Feasibility of Drug Screening with Panels of Human Tumor Cell Lines Using a Microculture Tetrazolium Assay, Cancer Reasearch, 48, 589-601 